\title{
Optimization of Virtual Water Trade with Emphasis on Agricultural Sector Support From Two Perspectives: Maximizing Farmers' Welfare and Employment.
}

\section{Fahimeh Bahrami}

Institute for Trade Studies and Research

Somayeh Avazdahandeh ( $\sim$ somayeh.avazdahandeh@modares.ac.ir )

Tarbiat Modares University Faculty of Agriculture https://orcid.org/0000-0002-8624-6620

Seyed Fazlollah Ranjbaran

Tarbiat Modares University Faculty of Agriculture

Mohammad Reza Nazari

Shahid Beheshti University

\section{Research Article}

Keywords: Virtual Water, Agricultural Sector, Multi - Objective Programming, Welfare, Employment

Posted Date: January 25th, 2022

DOI: https://doi.org/10.21203/rs.3.rs-1167478/v1

License: (c) (1) This work is licensed under a Creative Commons Attribution 4.0 International License.

Read Full License 


\title{
Optimization of Virtual Water Trade with Emphasis on Agricultural Sector Support from Two Perspectives: Maximizing Farmers' Welfare and Employment.
}

\author{
Fahimeh Bahrami*, Somayeh Avazdahandeh"*, Seyed Fazlollah Ranjbaran ${ }^{* * *}$, Mohammad Reza \\ Nazari $^{* * * *}$ \\ * Department Of Institute for Trade Studies and Researches, Iran, Tehran: F.Bahrami@itsr.ir \\ ** Department of Tarbiat Modares University, Iran, Tehran: Somayeh.Avazdahandeh@modares.ac.ir \\ *** Department of Tarbiat Modares University, Iran, Tehran: Ranjbaran.f@ modares.ac.ir \\ ****Department of Shahid Beheshti University,Tehran, Iran, Mo_nazari@sbu.ac.ir
}

\begin{abstract}
Water scarcity has become a global issue in agriculture. Therefore, sustainable use of water resources is essential. A concept that many planners and experts have recently emphasized in the field of water management that is the water footprint and virtual water trade. The objectives of this study are to maximize farmers' welfare, minimizing water consumption and maximizing employment in agriculture simultaneously. Multi-objective mathematical programming method was used to achieve the research objectives. The results indicated that the area of crops and fruits in Iran is reduced compared to the base year, especially in the irrigated activity, Also, saving water is about 15 billion $\mathrm{m}^{3}$ due to the change of cultivation pattern. Based on the model results, 2 billion $\mathrm{m}^{3}$ of water are imported into Iran by changes in the pattern of trade. The proposed model states water- saving 15 billion $\mathrm{m}^{3}$. The model suggests if the goal of policy -makers is to increase
\end{abstract}


employment in agriculture or farmer's social welfare, it should cultivate more fruits than crops and If the goal is to protect the environment and save water, it should replace crops with fruits.

Key words: Virtual Water, Agricultural Sector, Multi - Objective Programming, Welfare, Employment.

\section{Introduction}

Today, water scarcity has caused a lot of problems in providing safe drinking water, adequate production of agricultural crops, and the general process of human life. Hence, providing conditions that ensure the sustainability of water resources requires that the use of water on a national or even global scale be investigated (Ming and Chen, 2013). The fact is that $70 \%$ of the Earth's surface is covered by water. However, only less than one percent of it is available as surface and underground water for human, plant and animal use. Most importantly, even the same amount has not been distributed evenly and equitably between regions and countries (Hausmann and Patrick, 2013). On the other hand, the scarcity of water resources will create a strong competition between different sectors of the economy to seize it. Given the high share of water use in agriculture, with a share of $70 \%$ of the total water resources, the world's largest water consumer (Molden, 2007). On the other hand, due to the low economic value of water in it than other consumer sectors, the change in cultivated area and pattern of agricultural crops, the change in the pattern of trade in crops, the impact on food security and farmers, welfare is one of the consequences of water scarcity in agriculture (Lui et al., 2014). In general, two categories of water scarcity can be introduced. 1 . The physical shortage of water resources due to population growth 
(Avazdahandeh and Khalilian, 2021) and, consequently, surplus of demand for water relative to its supply. 2. The economic shortage of water due to the potential for adaptation to water scarcity, influenced by technological conditions, credit, water resource management and economic policies, optimal allocations and water efficiency (Tuton and Ohlsson, 1999). But the reality is in many developing countries, including in Iran, the second category of shortages in relation to water resources is more important than the first category, perhaps the poor performance in this regard is the pressure exerted on the deficiencies of the first category is exacerbated. To overcome these constraints, various strategies, especially in the agricultural sector, are among the largest water users worldwide (Molden, 2007). Increasing water productivity through the development of new technologies, improving water technical efficiency (engineering), and choosing a virtual water market-based business strategy (Faramarzi, 2010; Garrido et al., 2011; Lui et al, 2014). In the meantime, the concept highlighted by many planners and economic experts and water resources for the sustainable management of water resources is recently the water footprint and, consequently, the issue of water trade in its virtual (World Bank, 2010). Virtual water is a combination of two concepts of agriculture and economics that emphasize water as a key input for production. From the agricultural point of view, the term refers to the amount of water used for agricultural production. While its economic meaning refers to the cost opportunity of water, the value of other uses of water (the production of alternative outputs in industries and mines or in reproduction activities) (Mekonen and Hoekstra, 2011; Wichlenz, 2004). The opportunity cost discussion on virtual water, is of paramount importance especially when limited resource efficiency has been investigated. The economic concept of virtual water is closely to the concept of relative advantage based on the abundance of water inputs (Allen, 2003; Reimer, 2012). Many studies have been done in the field of virtual water, for example: Gao, L et al (2014) used the 
model that had been used to assess mine water use strategies in a coal mine in Queensland, Australia. The simulation results indicated that some tested strategies could reduce water use costs by more than $40 \%$, and raw water needed by more than $50 \%$. Further, the optimization revealed more easy-to-handle strategies that could save more than $40 \%$ of pipeline water and reduce the risks of penalties associated with discharge and of losing production due to insufficient water. Lamastra, L et al (2017) showed that the composition of virtual water flows was different; Italy imports significant amounts of grey water from China, depending on the different environmental strategies adopted by the two selected countries. This difference could be also related to the fact that traded commodities were very different; the $91 \%$ of virtual water imported by Italy was connected to crops products, while the $95 \%$ of virtual water imported by China was related to the animal products. Considering national water saving and global water saving, appeared that Italy imports virtual water from China while China exerts pressure on its water resources to supply the exports to Italy. Fu, Y et al (2018) did a study that its objective was supplying the agricultural products virtual water trade evaluation system, determining quantitatively the virtual water flow within the region \& regional. Results indicated that the regional differences in virtual water content for each crop were significant, China had a trade surplus in global virtual water trade of agricultural products and China's agricultural products virtual water imports have increased year by year. Bazrafshan et al (2019) focused on the water footprint components, water footprint accounting and virtual water trading of Saffron Production at the provincial and national level. The average water footprint of the Saffron production in Iran was $4659 \mathrm{~m}^{3} \mathrm{~kg}^{-1}$. The share of green, blue, white, and grey water footprints are estimated as 12,42, 40, and 6 percent, respectively. The total water footprint of Saffron production was around $1541 \mathrm{MCM} \mathrm{yr}^{-1}$ that the share of exported virtual water

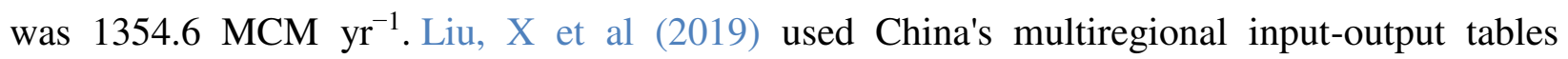


straddling two periods to trace the trade of a given region's three types of goods: local final goods, local intermediate goods, and goods that shipped to other regions and countries. They finded that goods traded inter-regionally in China in 2012 embodied $30.4 \%$ of all water used nationwide. Nationwide, water use increased substantially over 2007-2012 due to greater shipment volumes of water-intensive products. In fact, as suspected, the rise in value chain-related trade became a major contributing factor. Considering the importance of agriculture in the country's economy. Qasemipour et al (2020), Su et al (2014), Aldaya et al (2020) and Ye et al (2017) also studied about virtual water. The advantage of our study over other studies is that we have comprehensively considered both crops and fruits. No comprehensive study has been conducted in Iran so far also we considered welfare socially and employment virtual.. For example, Bazrafshan et al (2019) focused on the water footprint components, water footprint accounting and virtual water trading of Saffron Production at the provincial and national level. They did their study only Saffron. But we did our study for all crops and fruits. The objective of this research is to minimize virtual water trade, with the consideration of farmers' social welfare and virtual employment.

\section{Methodology}

\subsection{Assumptions and spatial scope of research}

In this research, according to the purpose of the study and Buckwell and Hazell (1972)'s suggestion, the climatic-agricultural characteristics of different regions of the country have been the basis of aggregated because it has taken into account the differences between regions in terms of both climate and agricultural factors in the modeling. Therefore, the FAO's Agro-Ecological Zoning System (AEZ) has been used. This zoning system is the main instrument FAO's of assessment of agricultural land potential and its characteristics at the global, regional, national and 
local levels. In this zoning system, Iran is divided into 10 broad agro-ecological zones based on climatic similarities (precipitation and temperature), soil type, types of crops.

Fig. 1. , The FAO's Agro-Ecological Zoning System

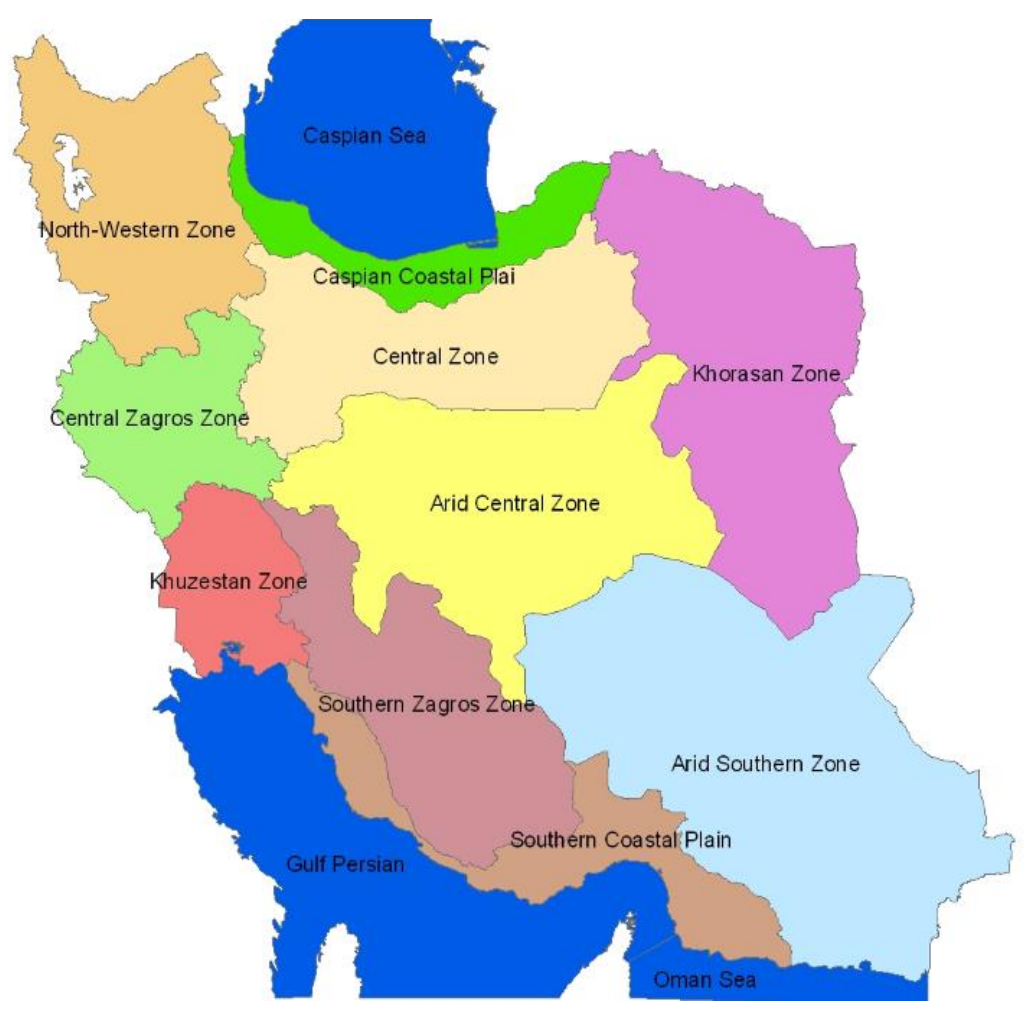

\subsection{Virtual water}

Numerous approaches and methodologies have been used in virtual water studies worldwide.

These studies are divided into two general categories in terms of approach and six in terms of methodology. The following picture illustrates the classification based on these two approaches. As can be seen in the picture above, the computational approaches are generally divided into two groups from bottom to top and top to bottom, each of which is performed in different ways. Life cycle based assessment is one of the standard methods for assessing the needs and environmental impacts of a crop throughout their cultivated period (Yang and et al, 2003). This is basically a bottom-up approach. The most commonly used approach for calculating virtual water content is 
the life cycle assessment method and then the model based on the crop growth period. The cropbased model also provides a systematic tool for calculating virtual water content in terms of the share of green and blue water used in crop production. It also enables the analysis of the effects of changes in various factors such as water availability, fertilizer application, and climate change on crop yield and water content.

Fig. 2. Methods used to calculate virtual water content

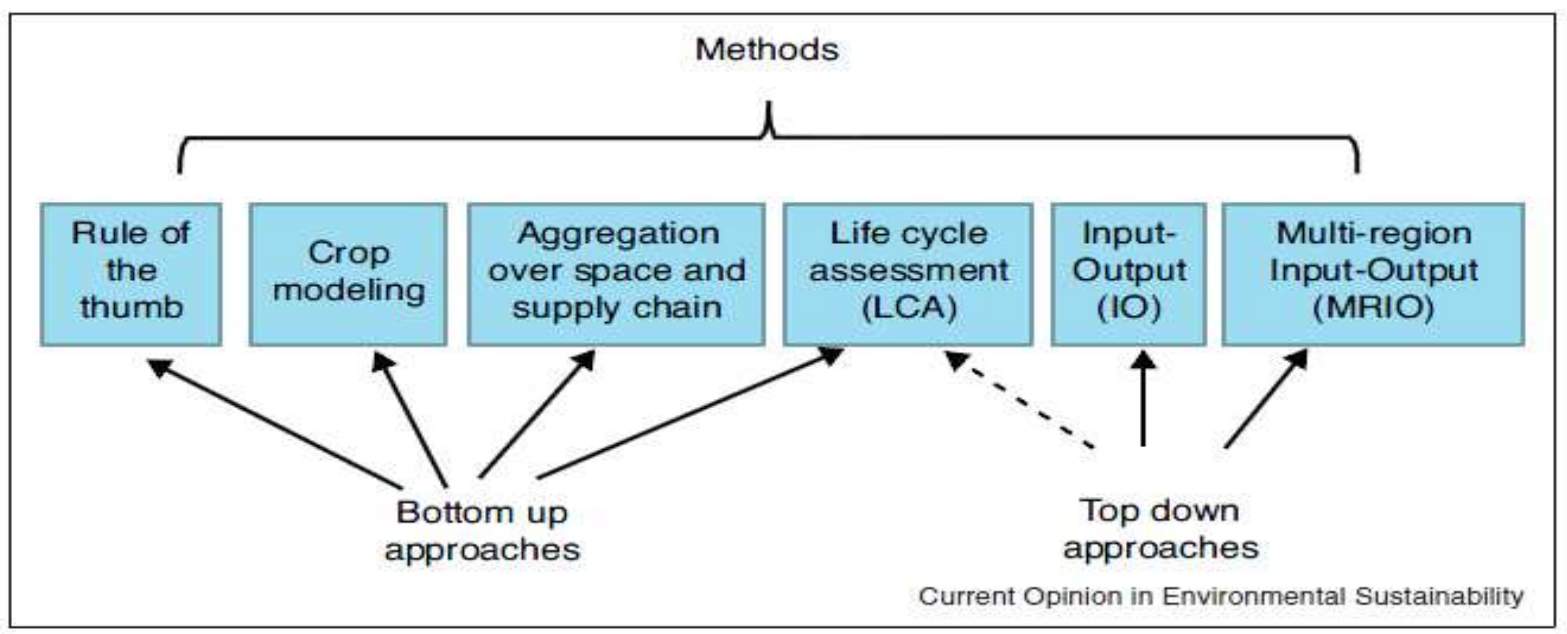

Resource: (Yang et al, 2003)

\subsection{Social value of crops and inputs}

\subsubsection{Water Valuation}

According to internal and external studies and review of Ministry of Energy documents for water pricing, the most common approach in Iran is the residual ratio approach. An important principle in the residual ratio approach is to use social (real) prices rather than market prices. In this method, first data on revenue and costs of a crop are calculated except water cost per unit area. Then, the value of water consumption per unit area is determined with the difference of incomes and costs. 


\subsubsection{Social value of products and other inputs}

The contents of this section are taken from the World Bank's Project Evaluation Guide published in 2012. Accordingly, in order to evaluate the social value of inputs and outputs, it is necessary to first calculate the shadow exchange rate and then calculate the social value of the inputs and outputs.

\subsubsection{Shadow exchange rate}

Exchange rate is an important factor in calculating the shadow social value of products and inputs. The exchange rate in Iran is highly volatile and it is affected by many factors, therefor it should be used the real exchange rate which represents the real purchasing power. There are different ways to calculate the shadow exchange rate. To calculate the shadow exchange rate, the theory of purchasing power equality can be used in both absolute and relative term.

The relative method is used to calculate it in this study. Because the consumer price index is more powerful in Iran and the price of gold in Iran is not sufficiently dynamic due to government interventionist policies. Using the relative purchasing power parity method, the shadow exchange rate (Rial or Toman vs. Dollar) is obtained from:

$$
E=E_{0}\left(P_{d} / P_{f}\right)
$$

In above relation, $\mathrm{P}_{\mathrm{d}}$ domestic consumer price index, $\mathrm{P}_{\mathrm{f}}$ foreign consumer price index, $\mathrm{E}_{0}$ free exchange rate in the base year and $\mathrm{E}$ is shadow exchange rate (Central Bank Balance Sheet of Iran, 2013). Then we evaluate the social value of inputs and outputs. Inputs in agriculture are divided into two groups of tradable and non- tradable inputs. Tradable inputs are a set of inputs 
that are traded internationally that in present study including various types of fertilizers, pesticides, seeds and part of machinery. Non-tradable inputs refer to internal inputs which include labor, land, manure and machinery.

\subsubsection{Social value of tradeable inputs}

To calculating of Social value of tradeable inputs, the cost - Insurance - Freight (CIF price) of inputs multiplies shadow exchange rate, then the average cost of shipping the goods plus it. Similarly, with respect to products imported to Iran, their social value is also calculated. In relation to exported goods, their free on board (FOB price) is based on the calculation of their social prices (Vishvanath, 1997).

2.3.2.3. Social value of non - tradeable inputs

To calculate the social value of non-trading inputs that do not have a boundary price, their market value is used to calculate social value. For example, for fertilizer, its market value is used (Vishvanath, 1997).

\subsection{Mathematical model}

The pattern of regional production and virtual water trade in the agricultural sector of Iran is considered a linear multi-objective model and set of linear constraints. The mathematical framework of this model is as follows: 
1) $M A X N S B$

$$
\begin{aligned}
& =\sum_{\mathrm{f}=1}^{14} \sum_{\mathrm{g}=1}^{10}\left(\operatorname{yeildzw}_{\mathrm{f}, \mathrm{g}} \times S P z w_{f, g}-S C z w_{f, g}\right) \times \operatorname{xcrop}_{\mathrm{f}, \mathrm{g}} \sum_{\mathrm{v}=1}^{12} \sum_{\mathrm{g}=1}^{10}\left(\operatorname{yeildzd}_{\mathrm{f}, \mathrm{g}} \times \operatorname{SPzd}_{\mathrm{v}, \mathrm{g}}\right. \\
& \left.-\operatorname{SCzd}_{\mathrm{v}, \mathrm{g}}\right)
\end{aligned}
$$

$\times \operatorname{xcropd}_{\mathrm{v}, \mathrm{g}}+\sum_{\mathrm{i}=1}^{12} \sum_{\mathrm{g}=1}^{10}$ yeildbw $_{\mathrm{i}, \mathrm{g}}\left(\mathrm{SPbw}_{\mathrm{i}, \mathrm{g}}{ }^{-}\right.$

$\left.\operatorname{SCbw}_{\mathrm{i}, \mathrm{g}}\right) \times \mathrm{xfruit}_{\mathrm{i}, \mathrm{g}}+\sum_{\mathrm{w}=1}^{8} \sum_{\mathrm{g}=1}^{10}$ yeildbd $_{\mathrm{i}, \mathrm{g}}\left(\mathrm{SPbd}_{\mathrm{i}, \mathrm{g}}-\mathrm{SCbd}_{\mathrm{i}, \mathrm{g}}\right) \times \mathrm{xfruitd}_{\mathrm{i}, \mathrm{g}}{ }^{-}$

$\sum_{\mathrm{b}=1}^{10} \sum_{\mathrm{g}=1}^{10} \sum_{\mathrm{gp}=1}^{9}\left(\operatorname{dis}_{\mathrm{g}, \mathrm{gp}} \times\right.$ tragsportz $\left._{\mathrm{b}, \mathrm{g}, \mathrm{gp}} \times \operatorname{trcost}_{\mathrm{b}, \mathrm{g}, \mathrm{gp}}\right)-$

$\sum_{\mathrm{a}=1}^{12} \sum_{\mathrm{g}=1}^{10} \sum_{\mathrm{gp}=1}^{9}\left(\operatorname{dis}_{\mathrm{g}, \mathrm{gp}} \times \operatorname{transportb}_{\mathrm{a}, \mathrm{g}, \mathrm{gp}} \times \operatorname{trcost}_{\mathrm{a}, \mathrm{g}, \mathrm{gp}}\right)+\sum_{\mathrm{b}=1}^{10} \sum_{\mathrm{g}=1}^{10}\left(\right.$ pez $_{\mathrm{b}} \times \operatorname{exportz}_{\mathrm{b}, \mathrm{g}}{ }^{-}$

$\left.\operatorname{piz}_{\mathrm{b}} \times \operatorname{importz}_{\mathrm{b}, \mathrm{g}}\right)+\sum_{\mathrm{b}=1}^{20} \sum_{\mathrm{g}=1}^{10}\left(\right.$ peb $_{\mathrm{a}} \times \operatorname{exportb}_{\mathrm{a}, \mathrm{g}} \mathrm{g}^{-}$

pib $_{\mathrm{a}} \times$ importb $\left._{\mathrm{a}, \mathrm{g}}\right)+\sum_{\mathrm{f}=1}^{14} \sum_{\mathrm{g}=1}^{10} \mathrm{Pwz}_{\mathrm{f}, \mathrm{g}} \times \frac{\mathrm{ETz}_{\mathrm{f}}}{\text { yeildz }_{\mathrm{f}}}\left(\right.$ importz $_{\mathrm{f}^{-}}$

exportz $\left._{\mathrm{f}}\right)+\sum_{\mathrm{i}=1}^{12} \sum_{\mathrm{g}=1}^{10} \mathrm{Pwb}_{\mathrm{i}, \mathrm{g}} \times \frac{\mathrm{ETb}_{\mathrm{i}}}{\text { yeildb }_{\mathrm{i}}}\left(\right.$ importb $_{\mathrm{i}}$ - exportb $\left._{\mathrm{i}}\right)$

2) MAX LAM $=\sum_{\mathrm{g}=1}^{10} \sum_{\mathrm{b}=1}^{26} 1_{\mathrm{b}, \mathrm{g}} \times \operatorname{xcrop}_{\mathrm{b}, \mathrm{g}}+\sum_{\mathrm{g}=1}^{10} \sum_{\mathrm{a}=1}^{20} 1_{\mathrm{a}, \mathrm{g}} \times$ xfruit $_{\mathrm{a}, \mathrm{g}}-\sum_{\mathrm{b}=1}^{26} \frac{\mathrm{l}_{\mathrm{b}}}{\text { yeildz }_{\mathrm{b}}} \times\left(\right.$ importz $_{\mathrm{b}}-$

$\left.\operatorname{exportz}_{\mathrm{b}}\right)-\sum_{\mathrm{a}=1}^{20} \frac{\mathrm{l}_{\mathrm{a}}}{\text { yeildb }_{\mathrm{a}}} \times\left(\right.$ importb $_{\mathrm{a}}$-exportb $\left._{\mathrm{a}}\right)$ 
3) Min WAT $==\sum_{\mathrm{f}=1}^{14} \frac{\mathrm{ET}_{\mathrm{f}, \mathrm{g}}^{\mathrm{a}}}{\text { efirre }_{\mathrm{g}}} \times\left(1-\right.$ definx $\left._{\mathrm{f}, \mathrm{g}}\right) \times \mathrm{xcrop}_{\mathrm{f}, \mathrm{g}}+\sum_{\mathrm{i}=1}^{12} \frac{\mathrm{ET}_{\mathrm{i}, \mathrm{g}}^{\mathrm{a}}}{\text { efirre }_{\mathrm{g}}} \times$ definx $_{\mathrm{i}, \mathrm{g}} \times \mathrm{xfruit}_{\mathrm{i}, \mathrm{g}}$

$\sum_{g=1}^{10}\left(\right.$ Swat $_{g}+$ Gwat $\left._{g}\right) \leq 0$

4) $-\sum_{b=1}^{26}$ yeild $_{b, \mathrm{~b}, g}(1-\%$ seed $) \times x$ crop $_{\mathrm{b}, \mathrm{g}}+t_{b, g} \leq 0 \quad \forall b, g$

$-\sum_{\mathrm{b}=1}^{26}$ convertz $_{\mathrm{b}, \mathrm{g}} \times \mathrm{t}_{\mathrm{b}, \mathrm{g}}+\sum_{\mathrm{b}=1}^{26}$ natcogz $_{\mathrm{b}, \mathrm{g}}-$

$\sum_{\mathrm{b}=1}^{26} \sum_{\mathrm{g}=1}^{9} \operatorname{transportz}_{\mathrm{b}, \mathrm{gp}, \mathrm{g}}+\sum_{\mathrm{b}=1}^{26} \sum_{\mathrm{gp}=1}^{9}$ transportz $_{\mathrm{b}, \mathrm{g}, \mathrm{g}}{ }^{-}$

$\sum_{\mathrm{b}=1}^{26}$ importz $_{\mathrm{b}}+\sum_{\mathrm{b}=1}^{26} \operatorname{exportz}_{\mathrm{b}} \leq 0 \quad \forall \mathrm{g}$

$-\sum_{\mathrm{i}=1}^{12}$ yeildbw $_{\mathrm{i}, \mathrm{g}} \times \mathrm{xfruit}_{\mathrm{i}, \mathrm{g}}-\sum_{\mathrm{w}=1}^{8}$ yeildbd $_{\mathrm{w}, \mathrm{g}} \times$ frruitd $_{\mathrm{w}, \mathrm{g}}+\sum_{\mathrm{a}=1}^{12} \mathrm{xw}_{\mathrm{a}, \mathrm{g}} \leq 0 \quad \forall \mathrm{a}, \mathrm{g}$

$-\sum_{\mathrm{a}=1}^{20} \operatorname{convertb}_{\mathrm{a}, \mathrm{g}} \times \mathrm{t}_{\mathrm{a}, \mathrm{g}}+\sum_{\mathrm{a}=1}^{20}$ natcogb $_{\mathrm{a}, \mathrm{g}}-$

$\sum_{\mathrm{a}=1}^{20} \sum_{\mathrm{gp}=1}^{9} \operatorname{transportb}_{\mathrm{a}, \mathrm{gp}, \mathrm{g}}+\sum_{\mathrm{a}=1}^{20} \sum_{\mathrm{gp}=1}^{9} \operatorname{transportb}_{\mathrm{b}, \mathrm{g}, \mathrm{gp}}{ }^{-}$

$\sum_{\mathrm{a}=1}^{20} \operatorname{importb}_{\mathrm{a}}+\sum_{\mathrm{a}=1}^{20} \operatorname{exportb}_{\mathrm{a}} \leq 0 \quad \forall \mathrm{g}$

$\sum_{\mathrm{f}=1}^{14} \mathrm{xcrop}_{\mathrm{f}, \mathrm{g}}-$-irrlandz $_{\mathrm{g}}+\sum_{\mathrm{v}=1}^{12} \mathrm{xcropd}_{\mathrm{v}, \mathrm{g}}-$ drylandz $_{\mathrm{g}} \leq 0 \quad \mathrm{f} \in \mathrm{b}, \quad \mathrm{v} \in \mathrm{b} \quad \forall \mathrm{g}$

$\sum_{\mathrm{i}=1}^{12} \mathrm{xfruit}_{\mathrm{i}, \mathrm{g}}$-irrlandb $_{\mathrm{g}}+\sum_{\mathrm{w}=1}^{8} \mathrm{xfruitd}_{\mathrm{w}, \mathrm{g}}-$-drylandb $_{\mathrm{g}} \leq 0 \quad \mathrm{i} \in \mathrm{a}, \mathrm{w} \in \mathrm{a} \quad \forall \mathrm{g}$

$\left(\sum_{\mathrm{f}=2,7,14} \operatorname{xcrop}_{\mathrm{f}, \mathrm{g}} \times\right.$ yeildzw $_{\mathrm{f}, \mathrm{g}}+\sum_{\mathrm{v}=2,7,12} \operatorname{xcropd}_{\mathrm{v}, \mathrm{g}} \times$ yeildzd $\left._{\mathrm{v}, \mathrm{g}}\right) \times \sum_{\mathrm{n}=1,2,3} \operatorname{tdn}_{\mathrm{n}}+\left(\sum_{\mathrm{f}=1,2} \mathrm{xcro}\right]$

In above equations, equation (2) is first objective function that shows net social benefit. Equation (3) is second objective function that implies employment in agriculture. Equation (4) is third objective function that shows water consumption in agriculture. Equation (5) and (6) indicates crop production and consumption ballance. Also, equation (7) and (8) showes fruits production and 
consumption ballance. In this model, the resource constraints include land and water resources. Equations (9) and (10) are land constraints for crops and fruits. Finally, equation (11) is livestock feed restriction. Model ${ }^{\mathrm{s}}$ subscripts are: crops: $\mathrm{b}=1,2,3, \ldots, 26, \mathrm{f}, \mathrm{v}$ : irrigated and dry crops fruits: $\mathrm{a}=1,2,3, \ldots, 20, \mathrm{i}, \mathrm{w}$ : irrigated and dry fruits and regions: $\mathrm{g}=1,2,3, \ldots, 10$.

\section{Result}

\subsection{Results of virtual water calculation}

In the first step, model ran through the application of multi objective mathematical programming method. Table 1 shows the amount of virtual water for irrigated crops and consumption value of one $\mathrm{m}^{3}$ of water in crop production in (2012-2013). Also Table 2 indicates the amount of virtual water for irrigated friuts and consumption value of one $\mathrm{m}^{3}$ of water in the same period. One thing to note about this Table: crops like rice, sugar beet and vegetables, there is little difference between the virtual water content in terms of quantity and value.

Table. 1. Virtual water for irrigated crops and consumption value of $1 \mathrm{~m}^{3}$ of water (2012-2013).

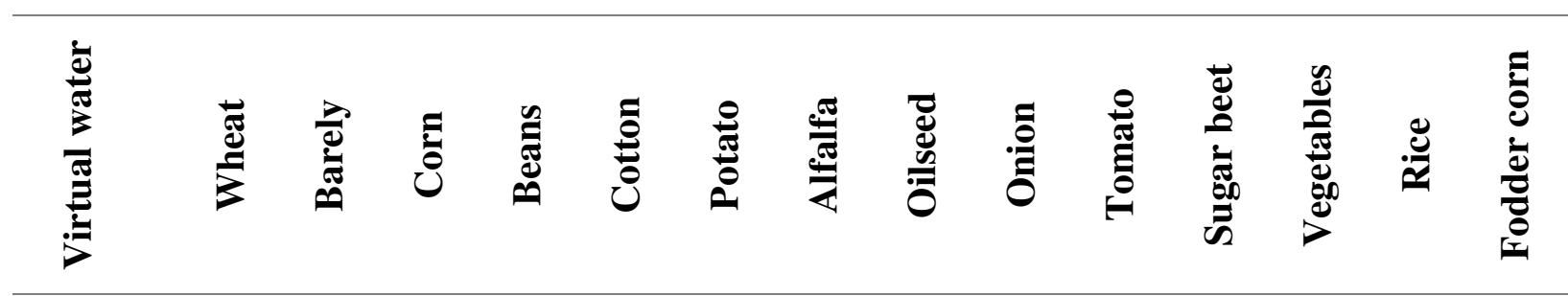

\section{Amoun}

$$
\mathbf{t}
$$

$\left(\mathrm{m}^{3} /\right.$ ton

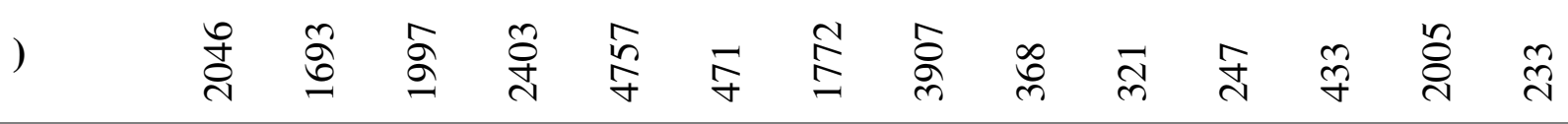




\section{Value}

(Toman

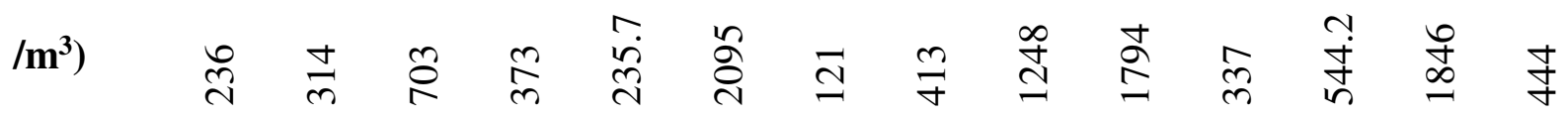

Source: Researcher's calculations.

Table. 2. Virtual water for irrigated fruits and consumption value of $1 \mathrm{~m}^{3}$ of water (2012-2013).

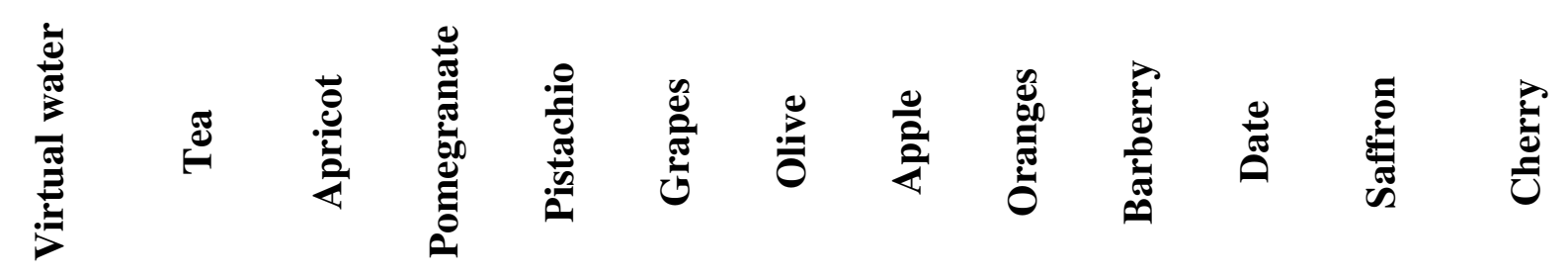

$\begin{array}{llllllllllllll}\text { Amou } & & & & & & & & & & & & \\ \text { nt } & & 201 & 136 & 836 & & 201 & 106 & & 637 & 613 & 13951 & 216 \\ & 1086 & & & & & 896 & & & 910 & & & & \\ \left(\mathbf{m}^{3} / \mathbf{t o}\right. & & 3 & 1 & 5 & & 9 & 3 & & 5 & 2 & 39 & 9\end{array}$

\begin{tabular}{|c|c|c|c|c|c|c|c|c|c|c|c|c|}
\hline Value & & & & & & & & & & & & \\
\hline & 3193. & 243 & 297 & 396 & 362 & & 210 & 399 & 361 & & & 389 \\
\hline $\left.\mathbf{n} / \mathbf{m}^{3}\right)$ & 6 & 1 & 0 & 1 & 9 & 401 & 9 & 7 & 6 & 913 & 5580 & 2 \\
\hline
\end{tabular}

n)

Source: Researcher's calculations.

The highest amount of virtual water is related to cotton, $4757\left(\mathrm{~m}^{3} /\right.$ ton $)$ and the lowest belongs to fodder corn. And the highest value was for the potato and the lowest value was for alfalfa. The highest amount of virtual water in fruits is related to saffron, with an average of $1395139\left(\mathrm{~m}^{3} / \mathrm{ton}\right)$. The exception of saffron, pistachio has the highest amount of virtual water about $8365\left(\mathrm{~m}^{3} /\right.$ ton). The lowest belongs to oranges with $910\left(\mathrm{~m}^{3} /\right.$ ton). Comparing the quantitative and valuable content of virtual water in fruits, we see that apricot has the same amount and value. The more important 
point is that value virtual water for pistachio, oranges and cherry is almost equal while the amount of virtual water is very different from each other.

The virtual water balance of crops has been showed in Table 3. As the calculations indicate, the net amount imports of water is about 35.5 billion $\mathrm{m}^{3}$. It means that Iran can save water in crops about 35.5 billion $\mathrm{m}^{3}$.

Table. 3. The virtual water balance of crops per billion $\mathrm{m}^{3}$

\begin{tabular}{lll}
\hline crops & Net export (ton) & Water balance (billion m3) \\
\hline Wheat & -3906800 & -7.99 \\
\hline Barely & -653213 & -1.1 \\
\hline Corn & -1955266 & -3.9 \\
\hline Beans & -182104 & -0.43 \\
\hline Cotton & 178403.9 & 0.08 \\
\hline Potato & 260026.5 & 0.09 \\
\hline Alfalfa & 765791.4 & 0.24 \\
\hline Oilseed & 601476.4 & 0.26 \\
\hline Onion & -11278561.6 & -2.8 \\
\hline Tomato & -54732.3 & -0.26 \\
\hline Sugar beet & -4264580 & -16.7 \\
\hline Vegetables & -37398.3 & -0.07 \\
\hline Rice & & 0.02 \\
\hline Fodder corn & & \\
\hline
\end{tabular}

Source: Researcher's calculations. 
Table 4 presents the virtual water balance of fruits per billion $\mathrm{m}^{3}$. Accordingly, Iran has imported about $401 \mathrm{~mm}^{3}$ water through the export of tea and olives in 2013 and has exported about 2961 $\mathrm{mm}^{3}$ water with the export of other fruits. The largest amount import water has been through tea and the largest amount export water has been through pistachio. In contrast, the lowest amount of water import has been through olive and the lowest amount export has been with barberry. Therefore, in horticulture sector unlike crop sector, $2560 \mathrm{~mm}^{3}$ water exits from Iran. By comparing the results of Tables 3 and Table 4, we conclude that if policy - makers want to save water and achieve environmental goals. They should seek to replace crops with horticulture crops.

Table. 4. The virtual water balance of fruits per billion $\mathrm{m}^{3}$

\begin{tabular}{lll}
\hline Fruits & Net export (ton) & Water balance (billion $\mathbf{~ m}^{\mathbf{3}}$ ) \\
\hline Tea & -35880.4 & -0.04 \\
\hline Apricot & 6480.097 & 0.01 \\
\hline Pomegranate & 12181.77 & 0.02 \\
\hline Pistachio & 124837 & 1.04 \\
\hline Grapes & 545629 & 0.48 \\
\hline Olive & -453.809 & -0.0009 \\
\hline Apple & 183319.2 & 0.19 \\
\hline Oranges & 98309.59 & 0.09 \\
\hline Barberry & 278.553 & 0.001 \\
\hline Date & 143750.2 & 0.9 \\
\hline Saffron & 136.605 & 0.2 \\
\hline Cherry & 15969.61 & 0.03 \\
\hline
\end{tabular}

Source: Researcher's calculations. 


\subsection{Model of proposed cropping pattern}

Table 5 compares the status of the virtual water trade balance in agriculture between the base year and the proposed model. As it can be seen, if the proposed model is implemented, about 2 billion $\mathrm{m}^{3}$ water will be imported into the country, which could be a reduction of pressure on water resources.

Table 5. Comparation of the virtual water trade balance between the base and proposed model (crops).

\begin{tabular}{llll}
\hline & proposal model & Base model & Rate \\
\hline Export of virtual water $\left(\mathbf{m m}^{\mathbf{3}}\right)$ & 2176.6 & 835.5 & 1.6 \\
\hline Import of virtual water $\left(\mathbf{m m}^{\mathbf{3}}\right)$ & 37525.6 & 33054.2 & 0.13 \\
\hline Net export of virtual water $\left(\mathbf{m m}^{\mathbf{3}}\right)$ & -35349 & -32218.6 & 0.1 \\
\hline
\end{tabular}

Source: Researcher's calculations.

Table 6 compares the state of virtual water balance in the garden sector between the base year and the proposed model. As shown in the Table, if the proposed pattern is implemented that it will result in $0.24 \%$ increase at virtual water exports relation to base year.

Table. 6. Comparation of the virtual water trade balance between the base and proposed model (fruits).

\begin{tabular}{llll}
\hline & Proposal model & Base model & Rate \\
\hline Export of virtual water & 4048.6 & 3018.4 & 0.34 \\
$\left(\mathbf{m m}^{\mathbf{3}}\right)$ & & & \\
\hline
\end{tabular}


Import of virtual water

$\left(\mathbf{m m}^{3}\right)$

Net export of virtual water

$\left(\mathbf{m m}^{3}\right)$

Source: Researcher's calculations.

\subsection{Result of virtual labor trade}

As shown in Table 7, because Iran is a net importer of crops based on the proposed model, so it is an importer of labor in the agriculture trade sector. Iran in production of wheat was the largest importer of labor among other crops. On the other hand, alfalfa in Iran was the largest exporter of labor. So if politicians want to increase employment in the agricultural sector, they must cultivate crops that export labor.

Table. 7. Labor balance for crops.

\begin{tabular}{lll}
\hline Crops & Net export (ton) & Labor balance (Person - days /ton) \\
\hline Wheat & -7409303 & -68165587.6 \\
\hline Barely & -1318301 & -10941898.3 \\
\hline Corn & -2061878 & -19794028.8 \\
\hline Beans & -445096 & -12996803.2 \\
\hline Cotton & 547432.7 & 985378.86 \\
\hline Potato & 780079.5 & 1716174.9 \\
\hline Alfalfa & 2297536 & 5054579.2 \\
\hline
\end{tabular}




\begin{tabular}{lll}
\hline Crops & Net export (ton) & Labor balance (Person - days /ton) \\
\hline Oilseed & 1804429 & 4150186.7 \\
\hline Onion & -15175855 & -18211026 \\
\hline Tomato & 0 & 0 \\
\hline Sugar beet & -2833202 & -25215497.8 \\
\hline Vegetables & 0 & 0 \\
\hline Rice & 0 & 0 \\
\hline Fodder corn & 0 & 0
\end{tabular}

Source: Researcher's calculations.

Comparison of the crop export and import situation of virtual labor in the proposed model compared to the base year shows that the amount of labor export or employment creation is higher in the proposed model than the base year.

Table 8 examines the virtual commerce of labor in the fruit sector based on the proposed model. As can be seen, Iran's proposed model can be a net exporter of the virtual labor and create employment opportunities. According to the proposed model, Iran will have a $26 \%$ net export in the fruits sector as compared to the base year. Among fruits, pistachio and grapes exported the largest virtual labor. By comparing the virtual labor of horticultural and agricultural crops, if Iran is looking to maximize employment, it should cultivate more horticultural than agricultural crops because other than tea and apricot, other fruits are exporters of virtual labor. The total export of virtual labor of horticultural crops is much higher than that of agricultural crops. According to the results of Tables 7 and 8, in the specified period, Iran is a net importer of labor in the production of agricultural crops and a net exporter of labor in the field of horticultural crops. 
Table. 8. Labor balance for fruits.

\begin{tabular}{lll}
\hline fruits & Net export (ton) & Labor balance (Person - days /ton) \\
\hline Tea & -62953.1 & -1864914 \\
\hline Apricot & -22374.9 & -148490.6 \\
\hline Pomegranate & 31568.69 & 155839.6 \\
\hline Pistachio & 181289 & 4323329.4 \\
\hline Grapes & 742004.2 & 4323329.4 \\
\hline Olive & 1645.55 & 1590602.6 \\
\hline Apple & 316675.7 & 1745356.1 \\
\hline Oranges & 301426 & 1150657.4 \\
\hline Barberry & 5330.5 & 226382.21 \\
\hline Date & 94334.45 & 1140096.4 \\
\hline Saffron & 151.82 & 3355259.7 \\
\hline Cherry & 42125.48 & 253932.58 \\
\hline
\end{tabular}

Source: Researcher's calculations.

\subsection{Objective function values}

Table 9 gives the values of the target functions. As it can be seen, the social profit of crops has decreased in the proposed model compared to the base year, which is reasonable given the reduced cultivated area. It is important to note that this reduction is offse by the positive trade balance and storage of $\$ 6$ million due to increased exports. The opportunity created by 15 billion $\mathrm{m}^{3}$ reduction 
consumption of water resources against social profit reduction could also have a very high potential for welfare. In fact, in order to save water of one $\mathrm{mm}^{3}$, Iran should be waived from 0.0005 million Tomans of social benefits and 0.0002 day - person of employment of the labor.

Table 9. The values of the target functions

\begin{tabular}{llcl}
\hline Objective function & Proposal model & Base model & Rate \\
\hline Welfare (m Toman) & 114228930 & 131620360 & -0.13 \\
\hline Water $\left(\mathbf{m m}^{\mathbf{3}}\right)$ & 61702.73 & 76996.551 & -0.25 \\
\hline Employment (day- & 314863800 & 332472800 & -0.05 \\
person) & & & \\
\hline
\end{tabular}

Source: Researcher's calculations.

\section{Discussion and conclusion}

In this study, according to the method used in the studies of Fritcher et al (2004), Hoekstra and Hung (2005) and a number of other researchers, the CWR index of actual evapotranspiration (ETc) was used to calculate virtual water. The results of this calculation show that evapotranspiration and water requirement in virtual water content are uncontrolled components and irrigation efficiency and yield are controllable components. The results indicated that the highest virtual water of crops was for cotton $4757 \mathrm{~m}^{3} /$ ton and the lowest virtual water was for fodder corn 233 $\mathrm{m}^{3}$ /ton. These results are similar to Su et al (2014)'s study. In their paper, at the same time, the planting ratio of food crops, such as corn, reduces, while the planting ratio of cash crops, such as cotton, vegetables, and fruits, increases. Through regional virtual water strategy in the basin, with the crops of different districts having comparative advantages, the proportion of green water 
utilization and the blue water use efficiency are improved. Similar results were obtained in Ye et al (2017)'s research. They concluded that when considered the virtual water trade of eight agricultural products in water allocation procedure, the proportion of agricultural consumption decreased to $45 \%$ in total water demand, while the groundwater consumption decreased to $24 \%$ in total water supply. Virtual water trade overturned the traditional components of water supplied from different sources for agricultural consumption, and became the largest water source in Beijing.

The highest of net import water in the crop sector was about 17 billion $\mathrm{m}^{3}$ for oil seeds and the lowest was for maize 0.07 billion $\mathrm{m}^{3}$. On the other hand, the highest net export water was related to vegetables 0.26 billion $\mathrm{m}^{3}$ and the lowest was related to alfalfa about 0.02 billion $\mathrm{m}^{3}$. In total in crop sector and base year, Iran was net importer water 33.47 billion $\mathrm{m}^{3}$. In the proposed model of crop, the highest net import of virtual water was through wheat import 15.15 billion $\mathrm{m}^{3}$ and the lowest net import was through beans imports about 1.4 billion $\mathrm{m}^{3}$. Accordingly, the highest net export of virtual water was related to vegetables with 0.78 billion $\mathrm{m}^{3}$ and the lowest was for sugar beet exports with 0.000007 billion $\mathrm{m}^{3}$. Overall, in the field of crops, Iran will be a net importer of water at 35.7 billion $\mathrm{m}^{3}$, which increased by about 3 billion $\mathrm{m}^{3}$ compared to the base year.

In relation to fruits, the highest amount of virtual water (excluding saffron) was $8365 \mathrm{~m} 3$ /ton for pistachio, and the lowest was $910 \mathrm{~m} 3$ /ton for oranges. Also, the highest net import of water through tea was 0.04 billion $\mathrm{m}^{3}$ and the lowest was for olive 0.0009 billion $\mathrm{m}^{3}$. According to the results, the highest net export of fruits was related to export of pistachio 1.04 billion $\mathrm{m}^{3}$ and the lowest was through barberry export 0.001 billion $\mathrm{m}^{3}$. In total, Iran exported about 2.9 billion $\mathrm{m}^{3}$ of water through fruits in the base year. The proposed model states that the highest net export of virtual water in fruits sector was related to pistachio $\left(1.5\right.$ billion $\left.\mathrm{m}^{3}\right)$ and the lowest was through 
olive exports $\left(0.003\right.$ billion $\left.\mathrm{m}^{3}\right)$. In contrast, the highest net import water is through tea that it imports 0.06 billion $\mathrm{m}^{3}$ and the lowest is through apricot with 0.04 billion $\mathrm{m}^{3}$. Overall, in the proposed model, net export of water by fruits is about 3.5 billion $\mathrm{m}^{3}$. These results are similar to Qasemipour et al (2020)'s study. They showed that The results show that the northern part of the country, with no water scarcity, imported virtual water through the trade of goods and services, while severely water-scarce regions were net virtual water exporters. Iran had a net export of $1811 \mathrm{Mm} 3$ per annum. While blue water resources (surface and groundwater) accounted for $92.2 \%$ of the national water footprint, $89.1 \%$ of total exports were related to the agriculture sector. Aldaya et al (2020) also indicated that Spanish agricultural trade grew both in import and exports, overcoming water scarcity limitations with the virtual water trade, with net water imports being predominant and even widening the gap during the 1996-2006 period of study. The agricultural economy showed a clear dependence on virtual water imports in the form of cereals and animal feed, which has continued to grow in the last 25 years. The results of Oki et al (2017)'s study indicated same findings: water has an extremely low unit price, and a tremendous volume of water is consumed per person each day and the rich but water-scarce countries tend to reduce local water consumption by importing virtual water. Also they demonstrate that nations characterized by net virtual water exports have higher water resources and income per capita and that no countries fall below a certain threshold with respect to both GDP and water resources.

The results of calculating the economic value of water showed that the highest value of consumption of $1 \mathrm{~m}^{3}$ water was 2095 Tomans for potato and the lowest was 121 Tomans for alfalfa. Regarding the fruits, the highest value of $1 \mathrm{~m} 3$ was obtained 3997 Tomans from oranges and the lowest value 401 Tomans from olives. Our findings about economic value is similar to Lowe et al (2020). They showed that the total value of the virtual water used to produce one tonne of durum 
wheat pasta (\$212). More importantly, the case study also highlights how variations in economic value between multiple locations where durum wheat is cultivated (Saskatchewan $\$ 0.10 \mathrm{~m} 3$, Arizona $\$ 0.08 \mathrm{~m} 3$ and Baja California $\$ 0.24 \mathrm{~m} 3$ ) indicate relative water scarcity and thus impact, as well as the potential for a more efficient allocation of virtual water. Pouran et al (2017) also concluded that The economic value of blue water of West Azerbaijan, Bushehr, Isfahan, Semnan, Ilam provinces according to maximizing water productivity are 1461, 4060, 7240, 467 and 3927 Toman per cubic meter of blue water, respectively. In relation to gray water for West Azerbaijan 722 and for Isfahan is 833 Toman per cubic meter of gray water. In general, the provinces have more bad water situation, the economic value of water content of their products is higher.

In this study, a multi-objective planning model was used that its aims were to maximize social welfare, maximizing the value of virtual water trade as well as minimizing pressure on water resources and maintaining optimal employment. Using the proposed model, the welfare will be 11625790 million Tomans, the reduction of pressure on water resources will be about 15 billion $\mathrm{m}^{3}$ and the optimal employment level will be about 3148.63800 person-day. Regarding the virtual labor balance, the results of the proposed model show that although it imports crops and fruits then it will lead to import labor into the country (this represents an increase of about $18 \%$ compared to the base model), but instead, there will be a $79 \%$ growth in the export of labor through the export of crops.

\section{Recommendation}

According to the results of the research, by applying the proposed model, water consumption, profit and employment will decrease. On this basis and in view of the Iranian water crisis, therefore, in the country, if the goal of policy -makers is to increase employment in agriculture or 
farmer's social welfare, it should cultivate more fruits than crops and If the goal is to protect the environment and save water, it should replace crops with fruits.

\section{Declarations:}

Ethical Approval: All authors kept to the Ethical Responsibilities of Authors.

Consent to Participate: Not applicable.

Consent to Publish: The authors declare that they consent to publish this manuscript.

Competing of Interest: The authors declare that they have no confict of interest.

Authors Contributions: Conceptualization: Fahimeh Bahrami; Methodology; Somayeh

Avazdahandeh: Formal analysis, Writing - review; Mohammad Reza Nazari: Investigation;

Seyed Fazlollah Ranjbaran: editing.

Funding: No funding was received for conducting this study.

Availability of data and materials: The authors announce that there is no problem for sharing the used model and codes by make request to corresponding author.

\section{References}

Allan, J.A. 2003. Virtual Water- The Water, Food and Trade Nexus Useful Concept or Misleading Metaphor? International Water Institute, 28: 106-113.

Avazdahandeh, S., Khalilian, S. 2021. The effect of urbanization on agricultural water consumption and production: the extended positive mathematical programming approach. Environ Geochem Health 43: 247-258. https://doi.org/10.1007/s10653-020-00668-2 
Aldaya, M. M, Garrido, A. Llamas, R. (2020). Water Footprint and VirtualWater Trade: The Birth and Growth of a New Research Field in Spain, Water ,12, 2641; doi:10.3390/w12092641.

Bazrafshan, O., Ramezani, H., Gerkani, Z and Shamili, M. (2019). Virtual water trade and water footprint accounting of Saffron production in Iran. Agriculture Water Management, 213: 368 374.

Central Bank Balance Sheet of Iran, 2013.

Faramarzi, M., Yang, H., Mousavi, J., Schulin, R., Binder, C.R. and Abbaspour, K. 2010. Analysis of Intra-Country Virtual Water Trade Strategy to Alleviate Water Scarcity in Iran. Hydrolgy and Earth System Scince, 14: 1417-1433.

Fraiture, C.D., Ximing, C., Amerasinghe, U., Rosegrant, M. and Molden, D. 2004. Does International Cereal Trade Save Water? The Impact of Virtual Water Trade on Global Water Use. Value of Water Research Report Series, 4: 65-78.

$\mathrm{Fu}, \mathrm{Y}$ et al (2018). The virtual Water flow of crops between intraregional and interregional in mainland China. Agriculture Water Management, 208: 204 - 213.

Gao, L et al (2014). A systems model combining process-based simulation and multi-objective optimisation for strategic management of mine water. Environmental Modeling and Software, 60: $250-264$.

Garrio, A. Novo, P., and Vareto-Ortega, C. 2011. Are virtual water flows in Spanish grain trade consistent with relative water scarcity? Ecological Economic, 68(5): 1454-1464.

Hausmann, C. and Patrick, S. 2013. Contigency Planning: Trade, s Role in Sustaiable World Food. Aquatic Procedia, 1: 20 - 29. 
Hoekstra, A.Y. and Hung, P.Q. 2002. Virtual Water Trade: A Quantification of Virtual Water Flows between Nations in Relation to International Crop Trade, Value of Water Research Report Series, 12:26-47.

Hoekstra, A.Y. and Hung, P.Q. 2002. Virtual Water Trade: A Quantification of Virtual Water Flows between Nations in Relation to International Crop Trade, Value of Water Research Report Series, 12:26-47.

Hoekstra, A.Y. and Hung, P.Q. 2005. Globalization of Water Resources: International Virtual Water Flows in Relation to Crop Trade. Global Environmental Change, 15(1): 45-56.

Lamastra, L et al. 2017 .Virtual water trade of agri-food products: Evidence from italian-chinese relations. Science of the Total Environment, (599 - 600): $474-482$.

Liu, X et al (2019). Can virtual water trade save water resources? Water Research, In Press.

Liu, J., Hertel, T., Taheripour,F., Zhu, T. and Ringler,C. 2014. International trade buffers the impact of future irrigation shortfalls. Global Environmental Change, 29: 22-31.

Lowe, B. H., Oglethorpe, D. R., \& Choudhary, S. 2020. Shifting from volume to economic value in virtual water allocation problems: A proposed new framework and methodology. Journal of Environmental Management, 110239. doi:10.1016/j.jenvman.2020.110239.

Mekonnen, M.M. and Hoekstra, A.Y. 2011. National water footprint accounts: the green, blue and grey water footprint of production and consumption. Value of Water Research Report Series, 50:12-35. 
Ming, C.Z. and Chen, G.Q. 2013. Virtual water accounting for the globalized world economy: National water footprint and international virtual water trade. Ecological Indicators, 28: 142149.

Molden, D. 2007. Water for Food, Water for Life: A Comprehensive Assessment of Water Management in Agriculture, 14:28-46.

Pouran, R and et al. 2017. Evaluating the economic value of virtual water with maximizing productivity of Irrigation water, Applied Economic Studies, 6(21), 189-212.

Qasemipour, E and et al. 2020. Assessment of Virtual Water Flows in Iran Using a Multi-Regional Input-Output Analysis, Sustainability, 12, 7424, 1 - 19; doi:10.3390/su12187424.

Oki, T, Yano, Sh and Hanasaki, N. 2017. Economic aspects of virtual water trade, Environmental Research Letter, 12, 044002.

Reimer, J. 2012. On the economics of virtual water trade. Ecological Economics, 75: 135-139. Su, X. Li, J and Singh, V. P. 2014. Optimal Allocation of Agricultural Water Resources Based on Virtual Water Subdivision in Shiyang River Basin, Water Resour Manage, 28: $2243-2257$.

Turton, A. R. and Ohlsson, L. 1999. Water Scarcity and Social Stability:Towards a Deeper Understanding of Key Concept Need to Manage Water Scarcity in Developing Countries. $9^{\text {th }}$ Stockholm Water Symposion, 67-93.

Vishvanath, V. 1997 .Economics and Development Resource Center.

Wichelns, D. 2004. The Policy Relevance of Virtual Water Can be Enhanced by Considering Comparative Advantages. Agricultural Water Management, 66: 49-63.

World Bank, 2010. World Development Indicator. The World Bank Group. 
Yang, H., Reichert, P., Abbaspour, K.C. and Zehnder, A.J.B. 2003. A water resources threshold and its implications for food security. Environment and Science Technology, 37: 3048-3054. Ye, Q. and et al. (2017). Optimal allocation of physical water resources integrated with virtual water trade in water scarce regions: A case study for Beijing, China, Water Research. 